\title{
ПРОДУКТИВНЕ ДОВГОЛІТТЯ МОЛОЧНОЇ ХУДОБИ ЗА РІЗНИХ МЕТОДІВ РОЗВЕДЕННЯ
}

\author{
Н. П. МАЗУР 1 , С. І. ФЕДОРОВИЧ ${ }^{2}$, В. В. ФЕДОРОВИЧ ${ }^{3}$ \\ ${ }^{1}$ Інститут розведення і генетики тварин імені М.В.Зубия НААН (Чубинське, Украӥна) \\ babikn@i.ua \\ ${ }^{2}$ Інститут біології тварин НААН (Львів, Украӥна) \\ logir@ukr.net
}

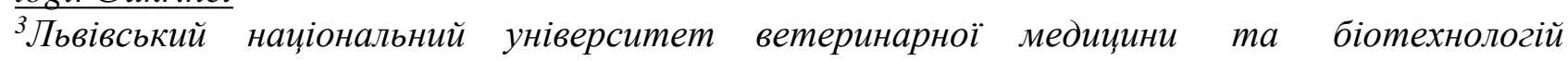
імені С. 3. Гжицького (Львів, Україна)

lionel@i.ua

Досліджено тривалість та ефективність продуктивного використання корів молочних порід за різних методів розведення. Встановлено, щзо кращими показниками продуктивного довголіття відзначалися чистопородні тварини вітчизняних порід порівняно з помісями, одержаними за поглинального схрещування з бугаями голштинської породи. 3 поміж чистопородних тварин голштинської, української чорно- та червоно-рябої молочних порід найдовще використовувалися у стадах (3,78 лактащіi) та мали найвищі довічні надої (19894 к2) корови української червоно-рябої молочної породи.

Найдовшою тривалістю життя, продуктивного використання, лактування та найбільшою кількістю лактацій за життя характеризувалися корови вітчизняних порід, частка спадковості голштинів у яких не перевищувала 50\%. 3 підвищенням у корів частки спадковості голштинської породи спостерігалося зниження їх довічних надоїв. Інтенсивність молокоутворення (надій на один день життя, продуктивного використання та лактування) найвищзю була у корів з високою часткою спадковості голштинів.

Зв'язки між умовною кровністю за голштинською породою та показниками продуктивного довголіття корів досліджуваних порід були слабкими за силою, проте у більшості випадків додатними і вірогідними $(P<0,001)$. Від'ємні значення коефічієнтів корелячії відмічено між часткою спадковості та надоями на один день продуктивного використання та лактування. Сила впливу умовної кровності за голштинською породою на показники тривалості та ефективності довічного використання корів української чорно- та червоно-рябої молочних порід коливалася від 9,0 до 34,3\%.

Ключові слова: порода, корови, чистопородне розведення, схрещування, умовна кровність, продуктивне довголіття, сила впливу

\section{PRODUCTIVE LONGEVITY OF DAIRY CATTLE WITH THE USE OF DIFFERENT METHODS OF BREEDING}

N. P. Mazur ${ }^{1}$, Ye. I. Fedorovych ${ }^{2}$, V. V. Fedorovych ${ }^{3}$

${ }^{1}$ Institute of Animal Breeding and Genetics nd. a. M.V.Zubets NAAS (Chubynske, Ukraine)

${ }^{2}$ Institute of Animal Biology NAAS (Lviv, Ukraine)

${ }^{3}$ Lviv National University of Veterinary Medicine and Biotechnologies named after S.Z.Gzhytskyy (Lviv, Ukraine)

It was studied the duration and effectiveness of productive use of cows of dairy breeds by different breeding methods. It was established that purebred animals of domestic breeds had better indicators of productive longevity in comparison with crossbreeds obtained by absorbing crossing with Holstein breeders. Among the purebred animals of Holstein, Ukrainian Black-, Red-and-White dairy breeds the last one were characterized by the longest use in herds (3.78 lactation) and the highest lifelong yields (19894 kg). 
Cows of Ukrainian dairy breeds, whose conditional bloodiness of the Holstein does not exceed $50 \%$ were characterized by the longest of life duration, productive use, lactation and the lifetime number of lactations. The increase of Holstein shares caused the reduce of their lifelong milk-yields. Animals with a high proportion of Holstein heredity had the highest intensity of milk production (yields per day of life, productive use and lactation).

The relationships between the conditional blood share by Holstein breed and the productive longevity of the studied cows were weak in strength, but in most cases they were positive $(P<0.001)$. Negative values of the correlation coefficients are marked between the share of heredity and yields per day of productive use and lactation. Strength of the influence of the share of heredity of Holstein on the indicators of duration and efficiency of life-long use of cows of Ukrainian Black- and Redand-White dairy breeds ranged from 9.0 to $34.3 \%$.

Keywords: breed, cows, purebred breeding, crossbreeding, conditional blood, productive longevity, strength of influence

\section{ПРОДУКТИВНОЕ ДОЛГОЛЕТИЕ МОЛОЧНОГО СКОТА ПРИ РАЗЛИЧНЫХ МЕТОДАХ РАЗВЕДЕНИЯ}

\section{Н. П. Мазур ${ }^{1}$, Е. И. Федорович ${ }^{2}$, В. В. Федорович ${ }^{3}$}

${ }^{1}$ Институт разведения и генетики животных имени М.В.Зубияа НААН (Чубинское, Украина)

${ }^{2}$ Институт биологии жсивотных НААН (Львов, Украина)

3Львовский национальный университет ветеринарной медищины и биотехнологий имени С. З. Гжичкого (Львов, Украина)

Исследовано продолжительность и эффективность продуктивного использования коров молочных пород при разных методах разведения. Установлено, что лучшими показателями продуктивного долголетия отличались чистопородные животные отечественных пород по сравнению с помесями, полученными от поглотительного скрещчивания с быками голштинской породы. Среди чистопородных животных голштинской, украинской черно- $u$ красно-пестрой молочных пород дольше использовались в стадах (3,78 лактачии) и имели самые высокие пожизненные удои (19894 к2) коровы украинской красно-пестрой молочной поpodbl.

Самой высокой продолжсительностью жизни, продуктивного использования, лактирования и наибольшим количеством лактаций при жизни характеризовались коровь отечественных пород, доля наследственности голштинов у которых не превышала 50\%. C повышением у коров доли наследственности голштинской породы наблюдалось снижение их пожизненных удоев. Интенсивность молокообразования (удой на один день жизни, продуктивного использования и лактирования) найвысшей была у коров с высокой долей наследственности голитинов.

Связи между условной кровностью по голштинской породе и показателями продуктивного долголетия коров исследуемых пород были слабыми по силе, однако в большинстве случаев положительными и достоверными $(P<0,001)$. Отрищательные значения коэффициентов корреляиии отмечено между долей наследственности и удоем на один день продуктивного использования и лактирования. Сила влияния условной кровности по голитинской породе на показатели продолжительности и эффективности пожизненного использования коров украинской черно- и красно-пестрой молочных пород колебалась от 9,0 до 34,3\%.

Ключевые слова: порода, коровы, чистопородное разведение, скрещивание, условная кровность, продуктивное долголетие, сила влияния

Вступ. Найважливішим і водночас найскладнішим питанням ведення молочного скотарства в умовах його інтенсифікації є забезпечення високого рівня продуктивності корів 3 одночасним довготривалим господарським використанням. Одним із ефективних шляхів докорінного поліпшення популяцій вітчизняних молочних порід, поряд з чистопородним розведенням, є використання генофонду кращих зарубіжних порід. Результативність ведення селекційно-племінної роботи з тваринами зумовлена не лише вдалим вибором поліпшуючої породи, 
а й пошуками кращого поєднання порід та зміною генетичної структури стада [2]. Застосування міжпорідних схрещувань, крім генетичного поліпшення багатьох селекційних ознак тварин, зокрема й продуктивного довголіття, дасть змогу отримати значний рівень мінливості, яка є обов'язковою для успішної селекції [1].

Покращення продуктивних якостей тварин трьох українських молочних порід здійснюється за допомогою поглинального схрещування з плідниками голштинської породи різних країн світу. За повідомленнями багатьох дослідників [3, 5, 8, 10-15], така односпрямована селекція призвела до погіршення рівня відтворення, продуктивного довголіття, якості продукції, загального здоров’я тварин тощо. Наразі вітчизняними науковцями ведеться пошук шляхів виправлення цієї ситуації. Зокрема, для покращення низки економічно важливих селекційних ознак у тварин, провідними вченими-селекціонерами країни, враховуючи світовий досвід, пропонується схрещувати голштинську і створених за ії участі вітчизняних молочних порід з неспорідненими сучасними заводськими породами європейської та північноамериканської селекції, що, на їх думку, дозволить отримати генетичний ефект гетерозису у помісей першого покоління. Використання для схрещування трьох неспоріднених порід дасть можливість підтримувати гетерозисний ефект у наступних поколіннях. Однак, вчені застерігають, що таке твердження потребує експериментальної перевірки і рекомендують для цього використовувати не більше 30\% маточного поголів'я племінних стад [9].

Основним напрямом подальшої селекційної роботи з молочними породами $\epsilon$ їх консолідація за типом, під яким розуміється не лише фенотип як результат реалізації генотипу в конкретних умовах, а й сукупність генетичної інформації, яка створює певний потенціал продуктивності тварини, iї адаптаційної та відтворної здатності. Тому основним завданням селекційної роботи є створення такої генотипової різноманітності тварин, яка здатна забезпечити стале відтворення бажаних ознак [7].

У цьому контексті важливим є вивчити такі невід'ємні ознаки бажаного типу як показники продуктивного довголіття корів молочних порід за різних методів розведення, що й визначило мету наших досліджень.

Матеріали та методи досліджень. Дослідження проведені на коровах голштинської $(\mathrm{n}=2396)$, української чорно- $(\mathrm{n}=12038)$ та червоно-рябої $(\mathrm{n}=1799)$ молочних порід. Ретроспективний аналіз тривалості та ефективності довічного використання корів здійснювали за методикою Ю. П. Полупана [6]. До вибірки залучено інформацію первинного зоотехнічного обліку 7 господарств з розведення голштинської породи (Рівненської, Вінницької, Київської, Чернігівської та Кіровоградської областей), 11 - з розведення української чорно-рябої молочної породи (Івано-Франківської, Львівської, Волинської, Рівненської, Вінницької, Київської, Черкаської та Кіровоградської областей) і 5 - з розведення української червоно-рябої молочної породи (Тернопільської, Вінницької, Київської та Черкаської областей). При формуванні бази даних ураховано всіх тварин, перше отелення яких датовано впродовж 1994-2008 років і що вибули зі стада після закінчення першої лактації тривалістю не менше 240 днів. Продуктивне довголіття корів оцінювали за такими ознаками: тривалість життя, господарського (продуктивного) використання, лактування, кількість лактацій за життя, довічний надій, середній вміст жиру в молоці, довічна кількість молочного жиру, надій на один день життя, продуктивного використання, лактування, коефіцієнт господарського використання (КГВ) і лактування (КЛ).

Статистичну обробку даних здійснювали за допомогою програмного пакету Мicrosoft Excel та "Statistica 6.1" за Г. Ф. Лакиным [4]. Результати середніх значень вважали статистично вірогідними при $\mathrm{P}<0,05(*), \mathrm{P}<0,01(* *), \mathrm{P}<0,001(* * *)$.

Результати досліджень. Основним методом удосконалення порід залишається чистопородне розведення із застосуванням за необхідності спорідненого міжпородного схрещування. Встановлено, що чистопородні корови молочних порід помітно відрізнялися між собою за показниками продуктивного довголіття (табл. 1). За більшістю показників тривалості та ефек- 
тивності довічного використання кращими були чистопородні корови української червоно-рябої молочної породи. Їх перевага над тваринами голштинської та української чорно-рябої молочної порід за тривалістю життя становила $508(\mathrm{P}<0,001)$ та 212 днів $(\mathrm{P}<0,05)$, продуктивного використання - відповідно $440(\mathrm{P}<0,001)$ та 261 день $(\mathrm{P}<0,05)$, лактування - 304 $(\mathrm{P}<0,001)$ та 88 днів, за кількістю лактацій за життя - 1,36 $(\mathrm{P}<0,001)$ та 0,21, за довічним надоєм - 667 та 1474 кг, за довічним вмістом жиру в молоці $-0,18(\mathrm{P}<0,001)$ та $0,18 \%$ $(\mathrm{P}<0,001)$ і за довічною кількістю молочного жиру - 62 та 90 кг (Р <0,05). Вищою інтенсивністю молокоутворення відзначалися корови голштинської породи. Надої на один день життя, продуктивного використання та лактування у них були достовірно $(\mathrm{P}<0,001)$ вищими порівняно з тваринами вітчизняних порід.

1. Продуктивне довголіття корів молочних порід за чистопородного розведення, $\mathrm{M} \pm \mathrm{m}$

\begin{tabular}{|c|c|c|c|}
\hline \multicolumn{1}{|c|}{ Ознака } & \multicolumn{3}{|c|}{ Порода } \\
\cline { 2 - 4 } & голштинська (Г) & $\begin{array}{c}\text { українська чорно- } \\
\text { ряба молочна } \\
\text { (УчРМ) }\end{array}$ & $\begin{array}{c}\text { українська червоно- } \\
\text { ряба молочна } \\
\text { (УЧеРМ) }\end{array}$ \\
\hline Кількість тварин, голів & 2396 & 2284 & 187 \\
\hline $\begin{array}{c}\text { Тривалість, дні: } \\
\text { життя }\end{array}$ & $1994 \pm 18,9 * * *$ & $2290 \pm 9,7 *$ & $2502 \pm 97,0$ \\
\hline господарського використання & $1141 \pm 18,1 * * *$ & $1320 \pm 9,8^{*}$ & $1581 \pm 89,1$ \\
\hline лактування & $935 \pm 15,2 * * *$ & $1151 \pm 8,3$ & $1239 \pm 64,7$ \\
\hline $\begin{array}{c}\text { Довічна продуктивність: } \\
\text { надій, кг }\end{array}$ & $19227 \pm 355,1$ & $18420 \pm 147,9$ & $19894 \pm 1029,7$ \\
\hline середній вміст жиру в молоці, \% & $3,65 \pm 0,005 * * *$ & $3,65 \pm 0,001 * * *$ & $3,83 \pm 0,017$ \\
\hline кількість молочного жиру, кг & $700 \pm 12,9$ & $672 \pm 5,4 *$ & $762 \pm 39,6$ \\
\hline Лактацій за життя & $2,42 \pm 0,044 * * *$ & $3,57 \pm 0,025$ & $3,78 \pm 0,191$ \\
\hline $\begin{array}{c}\text { Надій на 1 день, кг: } \\
\text { життя }\end{array}$ & $9,0 \pm 0,10$ & $8,1 \pm 0,05^{* * *}$ & $7,9 \pm 0,20^{* * *}$ \\
\hline господарського використання & $16,8 \pm 0,13$ & $14,4 \pm 0,06^{* * *}$ & $13,1 \pm 0,32^{* * *}$ \\
\hline лактування & $20,2 \pm 0,12$ & $15,8 \pm 0,08^{* * *}$ & $16,1 \pm 0,28^{* * *}$ \\
\hline Коефіцієнт господарського використання & $0,57 \pm 0,004 * * *$ & $0,57 \pm 0,003 * * *$ & $0,63 \pm 0,013$ \\
\hline Коефіцієнт лактування & $0,83 \pm 0,004 * * *$ & $0,86 \pm 0,002$ & $0,78 \pm 0,010^{* * *}$ \\
\hline
\end{tabular}

Примітка. Достовірність різниці між тваринами різних порід вказана при порівнянні до найвищого значення показників.

Необхідно зазначити, що серед загального поголів'я досліджуваних тварин кожної окремо взятої породи частка чистопородних корів є незначною: в українській чорно-рябій молочній породі - 19\%, а в українській червоно-рябій молочній - лише 9,5\%. Решту ж тварин отримано шляхом поглинального схрещування вітчизняних порід з голштинською. Таким чином було досягнуто значного підвищення рівня надою у корів, але тривалість їх продуктивного використання помітно знизилася (табл. 2). Помісні тварини української чорно-рябої молочної породи з різною спадковістю голштинів порівняно з чистопородними характеризувалися вірогідно $(\mathrm{P}<0,001)$ нижчими показниками тривалості життя - на 234 , продуктивного використання - на 244, лактування - на 237 днів, кількості лактацій за життя - на 1,15, довічного надою - на 3276 та довічної кількості молочного жиру - на 118 кг.

Чистопородні корови української червоно-рябої молочної породи достовірно (P < $0,01-$ $0,001)$ переважали помісних за тривалістю життя на 493, продуктивного використання - на 488 днів, лактування - на 1,17 лактації, довічним надоєм - на 3094 та довічною кількістю жиру - на 117 кг.

Показники надою на один день господарського використання та лактування вищими були у помісних тварин.

Як зазначалося раніше, у літературних джерелах є низка повідомлень про те, що з підвищенням частки спадковості голштинської породи у тварин вітчизняних молочних порід показники продуктивного довголіття знижуються. Ю. П. Полупаном [5] встановлено, що серед до- 
2. Продуктивне довголіття корів молочних порід, одержаних за двопорідного схрещування, $\mathrm{M} \pm \mathrm{m}$

\begin{tabular}{|c|c|c|c|c|}
\hline \multirow{3}{*}{ Ознака } & \multicolumn{4}{|c|}{ Поєднання порід } \\
\hline & \multicolumn{2}{|c|}{ УЧРМ х Г $(\mathrm{n}=9754)$} & \multicolumn{2}{|c|}{ УЧеРМ х Г $(\mathrm{n}=1612)$} \\
\hline & $\mathrm{M} \pm \mathrm{m}$ & $\mathrm{C}_{\mathrm{v}}, \%$ & $\mathrm{M} \pm \mathrm{m}$ & $\mathrm{C}_{\mathrm{v}}, \%$ \\
\hline Тривалість, дні: & & & & \\
\hline життя & $2056 \pm 7,2 * * *$ & 34,8 & $2009 \pm 21,9 * * *$ & 43,9 \\
\hline господарського використання & $1076 \pm 6,6^{* * *}$ & 60,7 & $1093 \pm 20,5 * * *$ & 75,1 \\
\hline лактування & $914 \pm 5,5 * * *$ & 59,1 & $887 \pm 14,9 * * *$ & 67,6 \\
\hline $\begin{array}{c}\text { Довічна продуктивність: } \\
\text { надій, кг }\end{array}$ & $15144 \pm 95,6^{* * *}$ & 62,3 & $16800 \pm 266,6 * *$ & 63,7 \\
\hline середній вміст жиру в молоці, \% & $3,67 \pm 0,001$ & 2,8 & $3,84 \pm 0,006$ & 6,4 \\
\hline кількість молочного жиру, кг & $554 \pm 3,5 * * *$ & 62,1 & $645 \pm 10,3 * *$ & 64,2 \\
\hline Лактацій за життя & $2,42 \pm 0,015 * * *$ & 61,7 & $2,61 \pm 0,044 * * *$ & 68,4 \\
\hline $\begin{array}{c}\text { Надій на } 1 \text { день, кг: } \\
\text { життя }\end{array}$ & $7,1 \pm 0,03 * * *$ & 41,6 & $7,9 \pm 0,08$ & 38,6 \\
\hline господарського використання & $14,6 \pm 0,05^{00}$ & 32,3 & $16,5 \pm 0,11^{000}$ & 27,3 \\
\hline лактування & $17,0 \pm 0,05^{000}$ & 30,7 & $19,4 \pm 0,10^{000}$ & 20,9 \\
\hline Коефіцієнт господарського використання & $0,49 \pm 0,001^{000}$ & 29,3 & $0,50 \pm 0,004 * * *$ & 32,3 \\
\hline Коефіцієнт лактування & $0,87 \pm 0,001 * * *$ & 13,4 & $0,84 \pm 0,003^{000}$ & 15,3 \\
\hline
\end{tabular}

Примітка. Достовірність різниці вказана при порівнянні показників у чистопородних (табл.1) та помісних тварин за голштинською породою: символом * позначено нижчі показники у помісей, а символом

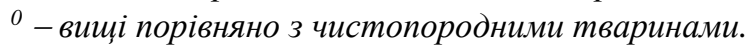

сліджуваних груп тварин з різною часткою спадковості за голштинською породою напівкровні помісі першого покоління відзначалися найвищими показниками тривалості життя, продуктивного використання та лактування. Підвищений прояв життєздатності у напівкровних помісей автор пояснює ефектом гетерозису. Подібні результати було отримано у наших дослідженнях. 3 поміж помісного поголів'я української чорно-рябої молочної породи найдовшою тривалістю життя, продуктивного використання, лактування та найбільшою кількістю лактацій за життя характеризувалися корови з умовною часткою спадковості голштинів 25-50\% (табл. 3). Їх перевага за цими показниками над тваринами інших кровностей за голштинською породою у всіх випадках була достовірною $(\mathrm{P}<0,01-0,001)$ : за тривалістю життя - на 203-585 днів, продуктивного використання - на 146-428, лактування - на 137400 днів і за кількістю лактацій за життя - на 0,25-0,79. У корів з умовною часткою спадковості голштинської породи 25-50\% відмічено вищий довічний надій порівняно 3 тваринами інших груп, однак у більшості випадків їх перевага була недостовірною. Надої на один день життя, продуктивного використання і лактування найвищими були у корів з високою часткою спадковості голштинів (понад 93,7\%).

3 поміж помісних тварин української червоно-рябої молочної породи кращими показниками тривалості життя, продуктивного використання, лактування та кількості лактацій за життя відзначалися тварини, умовна кровність за голштинською породою яких не перевищувала 50\% (табл. 4). За цими показниками вони достовірно (Р <0,001) переважали корів усіх груп, умовна частка спадковості голштинів у яких становила понад 75\%. Довічний надій та довічна кількість молочного жиру у корів з часткою спадковості голштинів до 50 та $50,1-$ $75,0 \%$ знаходилися майже на однаковому рівні і становили 18922-18931 та 720-737 кг відповідно.Надої на один день життя, продуктивного використання та лактування найвищими були також у тварин з генотипом понад 93,7\%.

Таким чином, у корів вітчизняних порід з підвищенням умовної кровності за голштинською породою понад 50\% відбувалося зниження тривалості життя, продуктивного використання, лактування та кількості лактацій за життя. Найнижчими ці показники відмічено у корів 3 часткою спадковості голштинів понад 87,6\%. Щодо довічних надоїв, то 3 насиченням генотипу корів голштинською породою також спостерігалося зниження цього показника. Якщо між тваринами різних генотипів української чорно-рябої молочної породи різниця за довічним надоєм була менш помітною і здебільшого невірогідною, то у особин різних генотипів україн- 


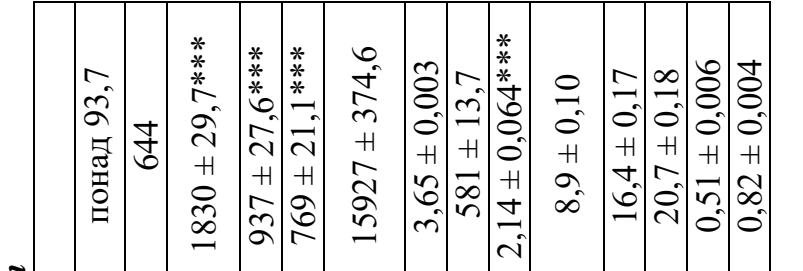

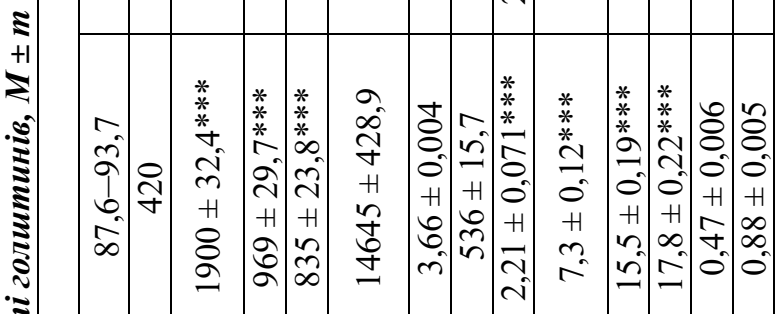

క

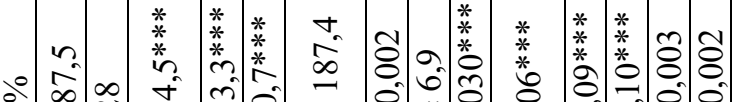

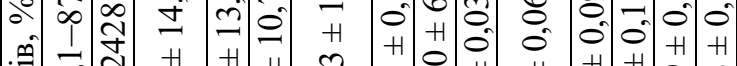

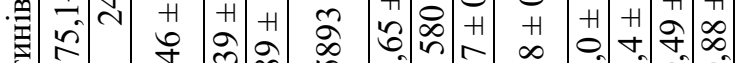

O

O

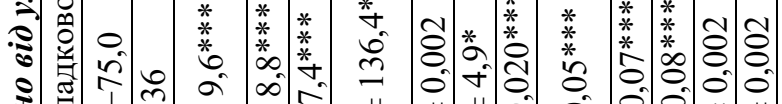

5

:

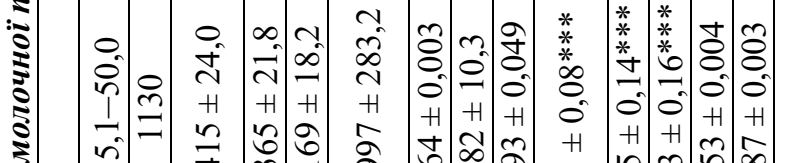

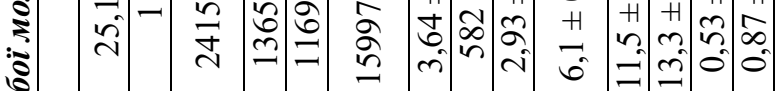



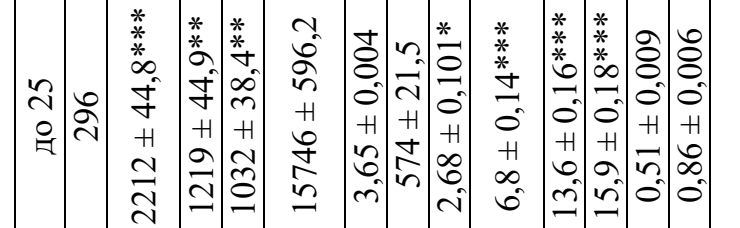

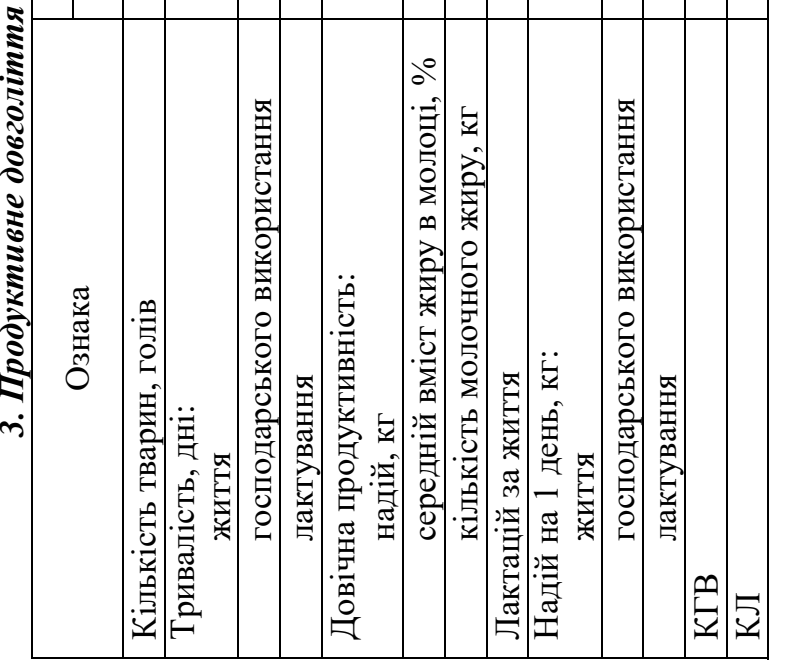

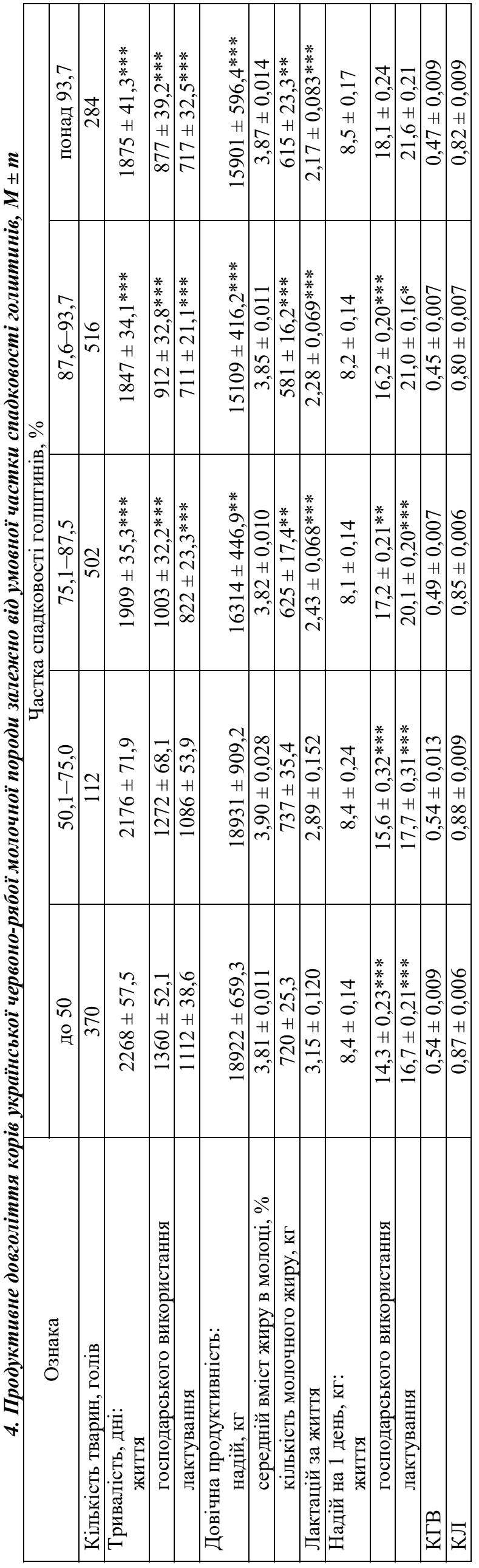


ської червоно-рябої молочної породи найвищий довічний надій відмічено у помісей з часткою спадковості голштинів до 75\%, а з підвищенням спадковості голштинів понад 75\% цей показник вірогідно (Р <0,01-0,001) знижувався.

Коефіцієнти кореляції між генотипом та тривалістю життя, продуктивного використання й лактування корів української чорно-рябої молочної породи коливалися від 0,097 до 0,144 та української червоно-рябої молочної породи - від 0,139 до 0,187 при $\mathrm{P}<0,001$ у всіх випадках (табл. 5).

5. Коефіцієнти кореляції міэс умовною часткою спадковості голитинів та показниками продуктивного довголіття корів вітчизняних молочних порід, $r \pm m_{r}$

\begin{tabular}{|l|c|c|}
\hline \multirow{2}{*}{ Корельована ознака } & \multicolumn{2}{|c|}{ Порода } \\
\cline { 2 - 3 } & УЧРМ (n=9754) & УЧеРМ (n $=1612)$ \\
\hline $\begin{array}{c}\text { Тривалість, дні: } \\
\text { життя }\end{array}$ & $0,097 \pm 0,009^{* * *}$ & $0,139 \pm 0,019^{* * *}$ \\
\hline господарського використання & $0,138 \pm 0,019^{* * *}$ & $0,187 \pm 0,035^{* * *}$ \\
\hline лактування & $0,144 \pm 0,021^{* * *}$ & $0,173 \pm 0,030^{* * *}$ \\
\hline $\begin{array}{c}\text { Довічна продуктивність: } \\
\text { надій, кг }\end{array}$ & $0,068 \pm 0,005^{* * *}$ & $0,140 \pm 0,019^{* * *}$ \\
\hline середній вміст жиру в молоці, \% & $-0,093 \pm 0,009^{* * *}$ & $0,021 \pm 0,000$ \\
\hline кількість молочного жиру, кг & $0,065 \pm 0,004^{* * *}$ & $0,139 \pm 0,019^{* * *}$ \\
\hline Лактацій за життя & $0,117 \pm 0,014 * * *$ & $0,169 \pm 0,028^{* * *}$ \\
\hline $\begin{array}{l}\text { Надій на 1 день, кг: } \\
\text { життя }\end{array}$ & $-0,006 \pm 0,000$ & $0,115 \pm 0,013^{* * *}$ \\
\hline господарського використання & $-0,129 \pm 0,017^{* * *}$ & $-0,022 \pm 0,000$ \\
\hline лактування & $-0,142 \pm 0,020^{* * *}$ & $0,006 \pm 0,000$ \\
\hline Коефіціснт господарського використання & $0,147 \pm 0,022^{* * *}$ & $0,207 \pm 0,043^{* * *}$ \\
\hline Коефіцієнт лактування & $0,015 \pm 0,000$ & $-0,077 \pm 0,006^{* *}$ \\
\hline
\end{tabular}

Зв’язки між умовною часткою спадковості та довічним надоєм і довічною кількістю молочного жиру корів досліджуваних порід були слабшими, а між умовною кровністю та надоями на один день життя, продуктивного використання та лактування - ще й оберненими.

Однофакторним дисперсійним аналізом виявлено вплив умовної кровності за голштинською породою на показники продуктивного довголіття корів вітчизняних порід (табл. 6).

6. Сила впливу умовної частки спадковості голитинів на продуктивне довголіття корів вітчизняних молочних порід

\begin{tabular}{|c|c|c|c|c|}
\hline \multirow{3}{*}{ Ознака } & \multicolumn{4}{|c|}{ Порода } \\
\hline & \multicolumn{2}{|c|}{ УЧРМ (n=9754) } & \multicolumn{2}{|c|}{ УЧеРМ $(\mathrm{n}=1612)$} \\
\hline & $\eta_{\mathrm{x}}^{2} \pm \mathrm{m}_{\eta}, \%$ & $\mathrm{~F}$ & $\eta_{\mathrm{x}}^{2} \pm \mathrm{m}_{\eta}, \%$ & $\mathrm{~F}$ \\
\hline $\begin{array}{c}\text { Тривалість, дні: } \\
\text { життя }\end{array}$ & $12,7 \pm 2,53 * * *$ & 5,7 & $31,5 \pm 4,48^{* * *}$ & 9,3 \\
\hline господарського використання & $12,7 \pm 2,53 * * *$ & 5,6 & $33,9 \pm 4,40 * * *$ & 10,3 \\
\hline лактування & $12,7 \pm 2,52 * * *$ & 5,7 & $31,2 \pm 4,49 * * *$ & 9,1 \\
\hline $\begin{array}{c}\text { Довічна продуктивність: } \\
\text { надій, кг }\end{array}$ & $9,0 \pm 2,55 * *$ & 3,8 & $26,3 \pm 4,63 * * *$ & 7,2 \\
\hline $\begin{array}{l}\text { середній вміст жиру в мо- } \\
\text { лоці, \% }\end{array}$ & $14,6 \pm 2,52 * * *$ & 6,7 & $9,9 \pm 4,93 *$ & 2,2 \\
\hline кількість молочного жиру, кг & $9,0 \pm 2,55 * *$ & 3,8 & $25,9 \pm 4,64 * * *$ & 7,0 \\
\hline Лактацій за життя & $11,0 \pm 2,54 * * *$ & 4,8 & $31,1 \pm 4,45^{* * *}$ & 9,1 \\
\hline $\begin{array}{c}\text { Надій на } 1 \text { день, кг: } \\
\text { життя }\end{array}$ & $10,5 \pm 2,54 * * *$ & 4,6 & $25,3 \pm 4,64 * * *$ & 6,8 \\
\hline господарського використання & $21,1 \pm 2,45 * * *$ & 10,5 & $25,6 \pm 4,65 * * *$ & 6,9 \\
\hline лактування & $21,3 \pm 2,46 * * *$ & 10,4 & $34,3 \pm 4,39 * * *$ & 10,5 \\
\hline $\begin{array}{l}\text { Коефіцієнт господарського } \\
\text { використання }\end{array}$ & $9,71 \pm 2,55 * * *$ & 4,2 & $27,5 \pm 4,59 * * *$ & 7,6 \\
\hline Коефіцієнт лактування & $5,77 \pm 2,56^{*}$ & 2,4 & $16,9 \pm 4,83 * *$ & 4,1 \\
\hline
\end{tabular}


Встановлено, що частка спадковості голштинів у тварин української чорно-рябої молочної породи дещо суттєвіше впливала на тривалість життя, продуктивного використання та лактування корів $(12,7 \%)$, ніж на їх довічний надій $(9,0 \%)$. Така ж ситуація спостерігалася і у тварин української червоно-рябої молочної породи: сила впливу умовної кровності за голштинською породою на тривалість життя, продуктивного використання та лактування знаходилася в межах 31,2-33,9\%, а на довічний надій та довічну кількість молочного жиру - в межах 25,9$26,3 \%$.

У тварин обох порід найвищу силу впливу вищеназваного фактора виявлено на надій на один день лактування: у корів української чорно-рябої молочної породи цей показник становив 21,3, української червоно-рябої молочної - 34,3\%.

У цілому коефіцієнти кореляції між часткою спадковості за голштинською породою та показниками продуктивного довголіття корів і сила впливу даного фактора на ці показники вищими були здебільшого у тварин української червоно-рябої молочної породи.

Висновки. Встановлено, що кращими показниками продуктивного довголіття відзначалися чистопородні тварини вітчизняних порід порівняно з помісями, одержаними за поглинального схрещування 3 бугаями голштинської породи. 3 поміж чистопородних тварин голштинської, української чорно- та червоно-рябої молочних порід найдовше використовувалися у стадах (3,78 лактації) та мали найвищі довічні надої (19894 кг) корови української червоно-рябої молочної породи.

Найдовшою тривалістю життя, продуктивного використання, лактування та найбільшою кількістю лактацій за життя характеризувалися корови вітчизняних порід, умовна частка спадковості голштинів у яких не перевищувала 50\%. 3 підвищенням частки спадковості голштинської породи спостерігалося зниження довічних надоїв: у корів різних генотипів української чорно-рябої молочної породи різниця за цим показником була менш помітною і здебільшого невірогідною, а у особин української червоно-рябої молочної породи з підвищенням спадковості голштинів понад 75\% довічні надої вірогідно $(\mathrm{P}<0,01-0,001)$ знижувалися. Інтенсивність молокоутворення (надій на один день життя, продуктивного використання та лактування) найвищою була у корів з високою часткою спадковості голштинів.

Зв’язки між генотипом та показниками продуктивного довголіття корів досліджуваних порід були слабкими, проте у більшості випадків додатними достовірними $(\mathrm{P}<0,001)$. Від'ємні значення коефіцієнтів кореляції відмічено між часткою спадковості та надоями на один день продуктивного використання та лактування.

Сила впливу умовної кровності за голштинською породою на показники тривалості та ефективності довічного використання корів української чорно- та червоно-рябої молочних порід коливалася від 9,0 до 34,3\%.

\section{БІБЛІОГРАФІЯ}

1. Бащенко, М. І. Досвід і перспективи використання кросбридингу в молочному скотарстві / М. І. Бащенко, О. І. Костенко, С. Ю. Рубан // Вісник аграрної науки. - 2016. - № 5. C. $28-33$.

2. Кальчук, Л. А. Тривалість використання та причини вибуття корів чорно-рябої породи різних генотипів і ліній / Л. А. Кальчук // Сільський господар. - 2004. - № 3-4. - С. 29-32.

3. Клопенко, Н. І. Генетична детермінація господарського використання корів молочного напряму продуктивності за вбирного схрещування / Н. І. Клопенко, Р. В. Ставецька // Технологія виробництва і переробки продукції тваринництва. - Біла Церква, 2015. - Вип. 1. - С. $23-$ 28.

4. Лакин, Г. Ф. Биометрия : учебное пособие [для биол. спец. вузов] / Г. Ф. Лакин. - (4-е изд., перераб. и доп.). - М. : Высшая школа, 1990. - 352 с.

5. Полупан, Ю. П. Ефективність довічного використання корів: до методики групування і вплив умовної кровності / Ю. П. Полупан // Розведення і генетика тварин. - К., 2014. - Вип. 48. - C. 98-113. 
6. Полупан, Ю. П. Методика оцінки селекційної ефективності довічного використання корів молочних порід / Ю. П. Полупан // Методологія наукових досліджень 3 питань селекції, генетики та біотехнології у тваринництві : матеріали наук.-теор. конф. (Чубинське, 25 лютого 2010 року). - К. : Аграрна наука, 2010. - С. 93-95.

7. Селекційні, генетичні та біотехнологічні методи удосконалення і збереження генофонду порід сільськогосподарських тварин / М. В. Гладій, М. І. Бащенко, Ю. П. Полупан, С. І. Ковтун, І. С. Бородай, Ю. В. Вдовиченко, В. М. Волощук, І. В. Гузєв, В. В. Дзіцюк, М. Я. Єфіменко, О. М. Жукорський, К. В. Копилов, В. І. Ладика, Ю. Ф. Мельник, О. І. Метлицька, І. П. Петренко, Б. Є. Подоба, С. Ю. Рубан, Т. М. Супрович, Л. М. Хмельничий, I. В. Базишина, Д. М. Басовський, О. Д. Бірюкова, О. В. Бойко, Л. В. Бондарчук, Р. В. Братушка, Л. В. Вишневський, С. Ю. Демчук, П. П. Джус, А. Б. Зюзюн, Г. Д. Іляшенко, Г. С. Коваленко, Т. П. Коваль, О. І. Костенко, А. П. Кругляк, О. В. Кругляк, Т. О. Кругляк, С. В. Кузебний, В. П. Олешко, Л. І. Остаповець, Ю. М. Павленко, М. Г. Порхун, К. Ф. Почерняєв, А. Є. Почукалін, Н. Л. Рєзникова, О.В.Сидоренко, Л. Ф. Стародуб, В. Ф. Стаховський, П. А. Троцький, Н. Г. Черняк, О. П. Чиркова, П. І. Шаран, Г. С. Шарапа, О. В. Щербак, І. М. Безрутченко, Г. М. Бондарук, С. М. Бриль, Л. О. Дєдова, О. В. Дуванов, С. С. Заблудовський, Н. М. Кузебна, Н. М. Маковська, І. С. Мартинюк, Н. І. Марченко, С. В. Прийма, Ю. М. Резнікова, В. А. Сіряк, А. М. Туряниця, Н. В. Чоп ; за ред. М. В. Гладія і Ю. П. Полупана ; ІРГТ ім. М.В.Зубця НААН. - Полтава : Фірма Техсервіс, 2018. - 791 с.

8. Стрекозов, Н. И. Продуктивное долголетие коров при голштинизации черно-пестрого скота / Н. И. Стрекозов, Н. В. Сивкин // Генетика и разведение животных. - 2014. - № 2. C. $11-16$.

9. Сучасний світовий досвід міжпородного схрещування у молочному скотарстві та його використання в Україні / М. І. Бащенко, М. М. Кваша, О.М.Жукорський, О. І. Костенко, М. В. Гладій, С. Ю. Рубан, А. П. Кругляк, Ю. П. Полупан, О. Д. Бірюкова, В. П. Шабля, Н. Г. Адміна, В. О. Даншин, О. О. Синицька, О. В. Бойко, Л. В. Мітіогло, М. М. Передрій, В. Г. Цибенко, А. Г.Пасюта, А. В. Шпортяк, В. І. Грек, А. В. Перекрестова ; за ред. М. І. Бащенка. - Київ : Аграрна наука, 2017. - 48 с.

10. Хмельничий, Л. М. Особливості спадкового впливу умовної кровності голштинської породи на показники довголіття корів української червоно-рябої молочної породи / Л. М. Хмельничий, В. В. Вечорка // Розведення і генетика тварин. - В., 2016. - Вип. 51. - С. 170-177.

11. Хмельничий, Л. М. Оцінка корів українських чорно-рябої та червоно-рябої молочних порід у порівнянні з голштинською худобою датської селекції за показниками довголіття / Л. М. Хмельничий // Вісник Сумського національного аграрного університету. Серія «Тваринництво». - 2017. - Вип. 7 (33). - С. 96-106.

12. Хмельничий, Л. М. Продуктивне довголіття корів молочної худоби в аспекті впливу генотипових та паратипових чинників / Л. М. Хмельничий, В.В.Вечорка, В. М. Бондарчук // Вісник Сумського національного аграрного університету. Серія «Тваринництво». - 2017. Вип. 7 (33). - С. 106-120.

13. De Vries, A. Economic trade-offs between genetic improvement and longevity in dairy cattle / A. De Vries // Journal of Dairy Science. - 2017. - Vol. 100, is. 6. - P. 4184-4192.

14. Genomic analysis of cow mortality and milk production using a threshold-linear model/ S. Tsuruta, D. A. L. Lourenco, I. Misztal, T. J. Lawlor // Journal of Dairy Science. - 2017. Vol. 100, is. 9. - P. 7295-7305.

15. Genomic evaluation of age at first calving. / J. L. Hutchison, P. M. VanRaden, D. J. Null, J. B. Cole, D. M. Bickhart // Journal of Dairy Science. - 2017. - Vol. 100, is. 8. - P. 6853-6861.

\section{REFERENCES}

1. Bashchenko, M. I., O. I. Kostenko, and S. Yu. Ruban. 2016. Dosvid i perspektyvy vykorystannia krosbrydynhu v molochnomu skotarstvi - Experience and prospects of crossbred use in dairy cattle breeding - Visnyk ahrarnoi nauky - Bulletin of Agrarian Science. 5:28-33 (in Ukrainian). 
2. Kalchuk, L. A. 2004. Tryvalist vykorystannia ta prychyny vybuttia koriv chorno-riaboi porody riznykh henotypiv i linii - Duration of use and reasons for the emergence of black currant cows of different genotypes and lines. Silskyi hospodar - Rural host. 3-4:29-32 (in Ukrainian).

3. Klopenko, N. I. and R. V. Stavetska. 2015. Henetychna determinatsiia hospodarskoho vykorystannia koriv molochnoho napriamu produktyvnosti za vbyrnoho skhreshchuvannia - Genetic determination of dairy cows economic usage by absorbing crossing. Tekhnolohiia vyrobnytstva $i$ pererobky produktsii tvarynnytstva - Animal Husbandry Products Production and Processing. 1:2328 (in Ukrainian).

4. Lakyn, H. F. 1990. Byometryia: uchebnoe posobye [dlia byol. spets. vuzov] - Biometrics: a tutorial [for biol. specialist. Universities]. M. : Vysshaia shkola. 352 (in Russian).

5. Polupan, Yu. P. 2014. Efektyvnist dovichnoho vykorystannia koriv: do metodyky hrupuvannia i vplyv umovnoi krovnosti - The efficiency of cows' lifetime use: concerning methodology for grouping and influence of conditional blood share. Rozvedennia i henetyka tvaryn - Animal Breeding and Genetics. K., 48:98-113 (in Ukrainian).

6. Polupan, Yu. P. 2010. Metodyka otsinky selektsiinoi efektyvnosti dovichnoho vykorystannia koriv molochnykh porid - Methods of assessing the efficiency of breeding lifetime use of dairy breeds of cows - Metodolohiia naukovykh doslidzhen $\mathrm{z}$ pytan selektsii, henetyky ta biotekhnolohii $u$ tvarynnytstvi : materialy naukovo-teoretychnoi konferentsii (Chubynske, 25 liutoho 2010 roku) Methodology of research on breeding, genetics and biotechnology in animal : materials of scientifictheoretical conference (Chubinskoe, 25 February 2010). 93-95 (in Ukrainian).

7. Hladii, M. V., M. I. Bashchenko, Yu. P. Polupan, S. I. Kovtun, I. S. Borodai, Yu. V. Vdovychenko, V. M. Voloshchuk, I. V. Huziev, V. V. Dzitsiuk, M. Ya. Yefimenko, O. M. Zhukorskyi, K. V. Kopylov, V. I. Ladyka, Yu. F. Melnyk, O. I. Metlytska, I. P. Petrenko, B. Ye. Podoba, S. Yu. Ruban, T. M. Suprovych, L. M. Khmelnychyi, I. V. Bazyshyna, D. M. Basovskyi, O. D. Biriukova, O. V. Boiko, L. V. Bondarchuk, R. V. Bratushka, L. V. Vyshnevskyi, S. Yu. Demchuk, P. P. Dzhus, A. B. Ziuziun, H. D. Iliashenko, H. S. Kovalenko, T. P. Koval, O. I. Kostenko, A. P. Kruhliak, O. V. Kruhliak, T. O. Kruhliak, S. V. Kuzebnyi, V. P. Oleshko, L. I. Ostapovets, Yu. M. Pavlenko, M. H. Porkhun, K. F. Pocherniaiev, A. Ye. Pochukalin, N. L. Rieznykova, O. V. Sydorenko, L. F. Starodub, V. F. Stakhovskyi, P. A. Trotskyi, N. H. Cherniak, O. P. Chyrkova, P. I. Sharan, H. S. Sharapa, O. V. Shcherbak, I. M. Bezrutchenko, H. M. Bondaruk, S. M. Bryl, L. O. Diedova, O. V. Duvanov, Ye. Ye. Zabludovskyi, N. M. Kuzebna, N. M. Makovska, I. S. Martyniuk, N. I. Marchenko, S. V. Pryima, Yu. M. Reznikova, V. A. Siriak, A. M. Turianytsia, and N. V. Chop. 2018. Selektsiini, henetychni ta biotekhnolohichni metody udoskonalennia i zberezhennia henofondu porid silskohospodarskykh tvaryn - Breeding, genetic and biotechnological methods for improving and preserving the gene pool of breeds of farm animals. Poltava, Firma Tekhservis, 791 (in Ukrainian).

8. Strekozov, N. I. and N. V. Sivkin. 2014. Produktivnoe dolgoletie korov pri golshtinizatsii cherno-pustrogo skota - Productive longevity of cows with golshtinizatsii Black-and-White cattle. Genetika i razvedenie zhivotnyih - Animal Genetics and Breeding. 2:11-16 (in Russian).

9. Bashchenko M. I., M. M. Kvasha, O. M. Zhukorskyi, O. I. Kostenko, M. V. Hladii, S. Yu. Ruban, A. P. Kruhliak, Yu. P. Polupan, O. D. Biriukova, V. P. Shablia, N. H. Admina, V. O. Danshyn, O. O. Synytska, O. V. Boiko, L. V. Mitiohlo, M. M. Peredrii, V. H. Tsybenko, A. H. Pasiuta, A. V. Shportiak, V. I. Hrek, and A. V. Perekrestova. 2017. Suchasnyi svitovyi dosvid mizhporodnoho skhreshchuvannia u molochnomu skotarstvi ta yoho vykorystannia v Ukraini - Modern world experience of inbred breeding in dairy cattle breeding and its use in Ukraine. Kyiv, Ahrarna nauka. 48 (in Ukrainian).

10. Khmel'nychyi, L. M. and V. V. Vechorka. 2016. Osoblyvosti spadkovoho vplyvu umovnoi krovnosti holshtynskoi porody na pokaznyky dovholittia koriv ukrainskoi chervono-riaboi molochnoi porody - Features of hereditary influence of holstein blood share on indicators of longevity of cows of Ukrainian Red-and-White dairy breed - Rozvedennia i henetyka tvaryn - Animal Breeding and Genetics. Vinnytsia. 51:170-177 (in Ukrainian). 
11. Khmel'nychyi, L. M. 2017. Otsinka koriv ukrainskykh chorno-riaboi ta chervono-riaboi molochnykh porid u porivnianni z holshtynskoiu khudoboiu datskoi selektsii za pokaznykamy dovholittia - The estimation of cows Ukrainian Black-and-White and Red-and-White dairy breeds in comparative with holstein cattle of danish breeding according to the longevity indicators - Visnyk Sumskoho natsionalnoho ahrarnoho universytetu - Bulletin of Sumy National Agrarian University. 7(33):96-106 (in Ukrainian).

12. Khmel'nychyi, L. M., V. V. Vechorka, and V. M. Bondarchuk. 2017. Produktyvne dovholittia koriv molochnoi khudoby $\mathrm{v}$ aspekti vplyvu henotypovykh ta paratypovykh chynnykiv - Productive longevity of dairy cows in the aspect of the influence of genotypic and paratypic factors - Visnyk Sumskoho natsionalnoho ahrarnoho universytetu - Bulletin of Sumy National Agrarian University. 7(33)106-120 (in Ukrainian).

13. De Vries, A. 2017. Economic trade-offs between genetic improvement and longevity in dairy cattle. Journal of Dairy Science. 100(6):4184-4192 (in English).

14. Tsuruta, S. D., A. L. Lourenco, I. Misztal, and T. J. Lawlor. 2017. Genomic analysis of cow mortality and milk production using a threshold-linear model. Journal of Dairy Science. 100(9):7295-7305 (in English).

15. Hutchison, J. L., P. M. VanRaden, D. J. Null, J. B. Cole, and D. M. Bickhart. 2017. Genomic evaluation of age at first calving. Journal of Dairy Science. 100(8):6853-6861 (in English).

УДК 636.27(477).033.082

\section{CHARACTER OF PRODUCTIVITY CHANGES IN GENERATIONS OF REGIONAL} FAMILIES OF VOLYNIAN BEEF CATTLE BREED

\section{A. E. POCHUKALIN \\ Institute of Animal Breeding and Genetics nd. a. M.V.Zubets of NAAS (Chubynske, Ukraine) pochuk.a@ukr.net}

The studies have been carried out on the breeding stock of Volynian beef breed of the breeding livestock farm LLC "Zorya" of Kovel district of the Volynian region. According to the primary zootechnical documentation, 18 regional families were formed. It has been established that for the majority of economically useful traits, most regional families have positive dynamics in generations. In 12 families, an increase on live weight at different age periods was noted with each subsequent generation, on milk productivity - at 11. Progressive for the complex of traits are the regional families of Arfa 599, Wisla 1016 and Kazka 433.

Keywords: family, foundation cow, breeding stock, regional family, milkiness, Volynian beef breed

\section{ХАРАКТЕР ЗМІН ПРОДУКТИВНОСТІ У ПОКОЛІННЯХ ЗАВОДСЬКИХ РОДИН ВО- ЛИНСЬКОЇ М'ЯСНОЇ ПОРОДИ ВЕЛИКОЇ РОГАТОЇ ХУДОБИ}

А. С. Почукалін

Інститут розведення і генетики тварин імені М.В.Зубия НААН (Чубинське, Україна)

Дослідження проведені на маточному поголів'ї волинської м'ясної породи великої рогатої худоби племінного заводу СТОВ «Зоря» Ковельського району Волинської області. За даними первинної зоотехнічної документації сформовано 18 заводських родин. Встановлено, щзо за господарськи корисними ознаками більшість заводських родин у поколіннях мають позитивну динаміку. Так, за живою масою корів у вікові періоди відмічено підвищення значення з кожним наступним поколінням у 12-ти родин, за молочністю - у 11-ти. Прогресуючими за

Розведення і генетика тварин. 2018. Вип. 55 